\title{
PENGARUH PEMBEKALAN KESEJAHTERAAN SPIRITUAL TERHADAP TINGKAT KECEMASAN KELUARGA PASIEN DI RUANG INTENSIVE CARE UNIT (ICU) RSD DR. SOEBANDI JEMBER
}

\author{
Muhammad Gufron \\ (Program Studi S1 Keperawatan, Fakultas Ilmu Kesehatan, Universitas \\ Muhammadiyah Jember, Email: Gufron7707@gmail.com) \\ Wahyudi Widada \\ (Fakultas Ilmu Kesehatan, Universitas Muhamadiyah Jember) \\ Fitriana Putri \\ (Fakultas Ilmu Kesehatan, Universitas Muhamadyah Jember)
}

\begin{abstract}
ABSTRAK
Intensive Care Unit (ICU) merupakan ruangan khusus dengan peralatan penunjang dan tenaga kesehatan terlatih untuk merawat pasien kritis yang mengancam jiwa sehingga sering menimbulkan kecemasan bagi keluarga pasien. Pembekalan kesejahteraan spiritual merupakan salah satu upaya menurunkan tingkat kecemasan pada keluarga pasien. Metode yang digunakan adalah pra eksperimen dengan pendekatan one grup pretest posttest design. Populasi dalam penelitian ini merupakan keluarga pasien yang dirawat di ruang ICU RSD dr. Soebandi Jember dengan jumlah sampel 30 keluarga pasien dengan tehnik purposive sampling. Pengumpulan data tingkat kecemasan menggunakan kuesioner HRS-A (Hamilon Rating Scale for Anxiety). Analisis data dengan uji Wilcoxon dan Shapiro Wilk Test. Tingkat kecemasan keluarga pasien yang dirawat di ruang ICU sebelum pembekalan kesejahteraan spiritual tingkat berat sekali $11(36.7 \%)$, berat $10(33.3 \%)$, sedang $4(13.3 \%)$, ringan 7 $(23.3 \%)$ dan normal 4 (13.3\%). Sesudah pembekalan kesejahteraan spiritual tingkat kecemasan keluarga pasien yang dirawat di ruang ICU berat sekali 2 $(6.7 \%)$, berat $9(30 \%)$, sedang $8(26.7 \%)$, ringan $7(23.3 \%)$, normal $4(13.3 \%)$. Pengukuran dengan tehnik uji wilcoxon menunjukkan nilai signifikan 0.000 $(\mathrm{P}<0,05)$, yang berarti ada perbedaan tingkat kecemasan keluarga pasien antara sebelum dilakukan intervensi dan sesudah dilakukan intervensi pembekalan kesejahteraan spiritual terhadap tingkat kecemasan keluarga pasien. Hasil penelitian ini diharapkan dapat dijadikan acuhan untuk melengkapi pelayanan Islami pada keluarga pasien dengan referensi kasus-kasus kecemasan di ruang ICU RSD dr Soebandi Jember.
\end{abstract}

Kata kunci : Kecemasan, Pembekalan Kesejahteraan Spiritual, Keluarga Pasien ICU

\section{ABSTRACT}

Intensive Care Unit (ICU) is a specialized room supported with sophisticated tools and well-trained health workers intended for taking care of patients in life threatening state thus causing high anxiety of their families. Giving support for encouraging spiritual welfare is an attempt to reduce the level of anxiety of patient's family. The research methode was pre-experimental design using the 
one group pretest posttest design. The population of the study includes families of patients in ICU room of dr Soebandi Hospital Jember, totaling 30 samples of family members resulted from the purposive sampling technique. The data of anxiety level was collected using the questionnaire of HRS-A (Hamilon Rating Scale for Anxiety). The data were analyzed using Wilcoxon and Shapiro Wilk test. The level of anxiety of families from patients in ICU room before given additional support of spiritual welfate was categorized as follows: very high 11 (36.7\%), high 10 33.3\%), medium 4 (13.3\%), low 3 (10\%) and normal 2 (6.7\%). After given additional support of spiritual welfare, the anxiety level turned to as follows: very high 2 (6.7\%), high 9 (30\%), medium 8 (26.7\%), low $7(23.3 \%)$, normal $4(13.3 \%)$. The measurement using Wilcoxon test indicated a significant value of $0.000(P<0,05)$, in other words there is a difference in the level of anxiety of families of patients nursed in ICU room of dr. Soebandi Hospital before and after given the intervention of additional support for spiritual welfare towards their anxiety. It is expected that this study finding can be a reference to be implemented as to complete Islamic services to patients' families by taking anxiety cases in ICU room of dr Soebandi Hospital Jember as examples.

Keywords : Anxiety, Support for Spiritual Welfare, Familiy of ICU Patients

\section{PENDAHULUAN}

Intensive Care Unit (ICU) adalah suatu bagian dari rumah sakit yang mandiri (instalasi dibawah direktur pelayanan), dengan staf yang khusus dan perlengkapan yang khusus yang ditunjukkan untuk observasi, perawatan, dan terapi pasien-pasien yang menderita penyakit, cedera atau penyulitpenyulit yang mengancam nyawa atau potensial mengancam dengan proknosis dubia. ICU menyediakan kemampuan dan sarana, prasarana peralatan khusus untuk menunjang fungsi-fungsi vital dengan menggunakan ketrampilan staf medik, perawat dan staf yang lain yang berpengalaman dalam pengelolaan keadaan-keadaan tersebut (Kemenkes RI, 2010).

$$
\text { Keluarga merupakan }
$$
supporting system yang sangat penting dalam proses penyembuhan pasien, apabila dukungan keluarga tidak didapatkan pasien, maka sangat berpengaruh pada proses penyembuhan dan pemulihan spiritual (Morton, Fontaine, Hudak, \& Gallo, 2013). Peran keluarga ini didukung dalam beberapa penelitian di Amerika, bahwa kehadiran keluarga sebagai fasilitator dan sumber informasi mengenai riwayat pasien, sebagai penyemangat, pemberi harapan, serta dapat membantu memberikan rasa aman dan nyaman bagi pasien (Mc Adam, Arai, \& Puntillo, 2008). Mengingat pentingnya peran keluarga bagi pasien kritis, pertama kali perawat Nancy Motter melakukan penelitian pada tahun 1979 tentang kebutuhan keluarga di ruang ICU, ditujukan untuk memenuhi kebutuhan keluarga pasien (Motter, 1979 dalam Freitas, Kimura, \& Ferreira, 2007).

Kecemasan adalah perasaan takut yang tidak jelas dan tidak didukung oleh situasi. Ketika merasa cemas, individu merasa tidak nyaman atau takut atau mungkin memiliki firasat akan ditimpa 
malapetaka padahal ia tidak mengerti mengapa emosi yang mengancam tersebut terjadi. Tidak ada obyek yang dapat diidentifikasi sebagai stimulus ansietas (Videbeck, 2008). Kecemasan suatu perasaan yang sifatnya umum, mengacu pada kondisi ketika individu merasakan kekhawatiran/kegelisahan,

ketegangan dan rasa tidak nyaman yang tidak terkendali mengenai kemungkinan akan terjadinya sesuatu yang buruk. Orang tersebut berada dalam kondisi maladaptif yang dicirikan dengan reaksi fisik dan perubahan psikologis (Richard, 2010). Apabila salah satu anggota keluarga yang sakit maka ikatan emosional anggota keluarga yang lain akan timbul yang menginterpretasikan dalam bentuk saling merasakan (Hudak \& Gallo, 2013).

Ada berbagai alasan yang dapat menyebabkan kecemasan keluarga pasien antara lain ketidaktahuan tentang penyakit atau kondisi yang dialami anggota keluarganya, serta ketidaktahuan tentang prosedur yang diberikan kepada anggota keluarganya yang sakit. Keluarga merupakan sistem pendukung utama yang memberi perawatan langsung pada setiap keadaan klien. Keluarga merupakan bagian dari manusia yang setiap hari selalu berhubungan dengan kita. Keadaan ini yang menyebabkan eratnya hubungan keluarga sebagai pendukung terdekat dari pasien saat mengalami sakit. Salah satu dukungan yang diberikan oleh keluarga adalah dukungan spriritual (Haqiki, 2013).

Dukungan spiritual juga dapat meringankan kondisi psikologis seperti takut, syok, putus asa, marah, cemas, dan depresi. Kekuatan spiritual seseorang yang rendah dapat menimbulkan permasalahan psiko- sosial di bidang kesehatan (Hamid, 2008). Spiritualitas merupakan kekuatan yang menyatukan, memberi makna pada kehidupan dan nilai-nilai individu, persepsi, kepercayaan dan keterikatan di antara individu (Kozier, 2004). Dalam situasi kerja spiritual well being mempermudah dalam menyelesaikan masalah, membantu terapis mencapai kekuatan emosional, mengurangi tingkat stres, sehingga dapat membantu menciptakan lingkungan kerja yang semangat, antusias dan dapat meningkatkan kemampuan mental seperti kejernihan berpikir dan pengambilan keputusaan (Singh, 2006). Tetapi pengaruh pembekalan kesejahteraan spiritual dengan kecemasan keluarga pasien ICU di Jember masih belum jelas.

Hasil studi pendahuluan yang dilakukan pada bulan Maret 2018 menyatakan bahwa jumlah pasien yang di rawat di ICU RSD dr. Soebandi Jember sebanyak 27 pasien, dengan diagnosa medis paling banyak COB (Cedera Otak Berat). Sebanyak 21 pasien Cidera Otak Berat (COB) yang telah dilakukan trepanasi dan 5 pasien meninggal, sebanyak 3 pasien dengan Eklamsia yang sudah dilakukan Sectio Caesaria dan 1 pasien meninggal, sebanyak 2 pasien Fraktur Cervical yang sudah dilakukan laminektomy dan 1 pasien meninggal, sebanyak 1 pasien close Fraktur Femur Dekstra dan 1 pasien dengan peritonitis yang sudah dilakukan laparatomi. Berdasar latar belakang di atas peneliti tertarik untuk meneliti pengaruh pembekalan kesejahteraan spiritual dengan tingkat kecemasan keluarga pasien 
yang dirawat di ruang ICU di RSD dr Soebandi Jember.

\section{DESAIN PENELITIAN}

Desain penelitian dalam
penelitian ini adalah desain Praeksperimen dengan pendekatan One Group Pretest Posttest yaitu suatu racangan dengan tidak ada kelompok pembanding (kontrol), tetapi paling tidak sudah dilakukan observasi pertama (pretest) yang memungkinkan menguji perubahanperubahan yang terjadi setelah adanya eksperimen (intervensi) (Notoatmodjo, 2012). Teknik pengambilan sampel yang digunakan dalam penelitian ini adalah nonprobability sampling. Jenis teknik

\section{HASIL PENELITIAN}

Responden dalam penelitian ini adalah keluarga pasien yang dirawat di ruang intensive care unit (ICU) di RSD dr. Soebandi Jember dengang yang dipilih adalah teknik purposive sampling. Pengambilan sampel secara purposive sampling ini dilakukan dengan menentukan sampel menggunakan pertimbangan tertentu dalam penentuannya sesuai dengan yang dikehendaki oleh peneliti (Notoatmojo, 2012).

Sampel dari penelitian ini adalah keluarga pasien yang ber agama Islam dan memiliki anggota keluarga dengan COB yang dirawat di ICU RSD dr.Soebandi Jember dengan berjumlah sampel 30 keluarga pasien dengan mengukur tingkat kecemasan dengan skala HARS (Hamilton Anxiety Rating Scale). Penelitian ini dilakukan pada bulan november 2018.

Tabel 1. Distribusi frekuensi keluarga dari penderita di ICU RSD. dr. Soebandi tahun 2018

\begin{tabular}{ccc}
\hline Jenis Kelamin & Frekuensi & Persentase \\
\hline Laki-laki & 10 & $33.3 \%$ \\
Perempuan & 20 & $66.7 \%$ \\
\hline Jumlah & 30 & $100 \%$ \\
\hline
\end{tabular}

Berdasarkan tabel 1 diketahui bahwa distribusi frekuensi responden dari keluarga yang dirawat di ruang ICU RSD jumlah responden sebanyak 30 orang. Pada tabel berikut disajikan data karakteristik subyek berdasarkan jenis kelamin 
Tabel 2. Distribusi frekuensi tingkat kecemasan pre intervensi dari keluarga penderita di ICU RSD. Dr. Soebandi tahun 2018

\begin{tabular}{|c|c|c|}
\hline Tingkat Kecemasan & Frekuensi & Persentase \\
\hline Normal & 2 & $6.7 \%$ \\
\hline Ringan & 3 & $10 \%$ \\
\hline Sedang & 4 & $13.3 \%$ \\
\hline Berat & 10 & $33.3 \%$ \\
\hline Berat sekali & 11 & $36.7 \%$ \\
\hline Jumlah & 30 & $100 \%$ \\
\hline
\end{tabular}

Berdasarkan tabel 2 diketahui bawah tingkat kecemasan keluarga yang dirawat di ruang ICU RSD dr.Soebandi Jember sebelum dilakukan intervensi sebagaian besar adalah mengalami tingkat kecemsan berat sekali sebanyak 11 orang atau (36.7\%).

Tabel 3. Distribusi frekuensi tingkat kecemasan post intervensi dari keluarga penderita di ICU RSD. Dr. Soebandi tahun 2018

\begin{tabular}{ccc}
\hline Tingkat Kecemasan & Frekuensi & Persentase \\
\hline Normal & 4 & $13.3 \%$ \\
Ringan & 7 & $23.3 \%$ \\
Sedang & 8 & $26.7 \%$ \\
Berat & 9 & $30.0 \%$ \\
Berat sekali & 2 & $6.7 \%$ \\
\hline Jumlah & 30 & $100 \%$ \\
\hline
\end{tabular}

Berdasarkan tabel 3 diketahui bawah tingkat kecemasan keluarga responden yang dirawat di ruang ICU RSD dr.Soebandi Jember setelah dilakukan intervensi sebagian besar adalah mengalami tingkat kecemasan berat sebanyak 9 orang $30 \%$.

Berdasarkan uji normalitas dengan menggunakan uji satistik Shapiro wilk diperoleh nilai sig untuk kelompok 1(pre intervensi) sebesar 0.205 sedangkan nila sig untuk kelompok 2 (post intervensi) sebesar 0.807. Karena nilai signifikansi kelompok 1 (pre intervensi dan kelompok 2 (post intervensi) > 0.05 maka kesimpulan data berdistribusi normal. Besar perhitungan korelasi antara variabel pembekalan kesejahteraan spiritual terhadap tingkat kecemasan pada keluarga dari penderita yang dirawat di ruang ICU RSD dr. Soebandi di Jember tahun 2018 dengan koefisien korelasi Nilai Z 4261 dan asym sig sebesar 0.000 (nilai p). Hasil menunjukkan bahwa nilai $\mathrm{p}=0.000<0.05$ yang berarti ada perbedaan yang signifikan tingkat kecemasan antara sebelum dilakukan intervensi dan setelah dilakukan intervensi.

\section{PEMBAHASAN}

Kecemasan merupakan suatu tanda yang memperingatkan adanya bahaya yang mengancam pada diri individu. Hasil penelitian ini menunjukkan bahwa sebelum 
dilakukan intervensi, tingkat kecemasan keluarga berada pada level cemas tingkat berat sekali yaitu 11 responden $36.7 \%$. Hasil penelitian ini sama dengan peneliti terdahulu bahwa kecemasan keluarga dapat berada pada tingkat berat bilamana ada keluarganya yang sakit dirawat di runag ICU. hasil penelitian Elias dan Susanti, (2013) menyatakan bahwa menyatakan bahwa dari 54 responden yang mengalami kecemasan tingkat berat sebanyak 40 responden $(74 \%)$. Sebagaian besar penunggu pasien di ruang ICU RSD dr Soebandi Jember adalah keluarga dekat dari pasien yaitu orang tua pasien sehingga ikatan yang terjalin aantara anak dengan orang tua sangat kuat baik katan emosi ataupun psikologis (Sugimin, 2017). Akibat kekerabatan yang baik di dalam keluarga sehingga bila ada anggota keluarga yang sakit dapat menimbulkan reaksi emosi oleh karena pasien berada pada kondisi kritis hal menimbulkan kecemasna pada tingkat berat (Kristianai, 2017).

Kesejahteraan spiritual merupakan perasaan harmonis dari seseorang ketika menemukan keseimbanagn antara nilai, tujuan dan keyakinan dalam diri seseorang dan orang lain (Potter \& Perry, 2005). Dengan pembekalan kesejahteraan spiritual melalui proses bimbingan diharapkan sesoerang memilki sifat kesadaran, kesabaran yang akhirnya ibadah-ibadah bagi keluarga pasien dapat terlaksana dengan baik. Hasil penelitian ini menunjukkan bahwa setelah dilakukan pembekalan kesejateraan spiritual tingkat kecemasan yang berat pada tingkat berat sekali yang semula $11(36.7 \%)$ berkurang menjadi $2(6.7 \%)$. Hasil ini memebuktikan bahwa pembekalan kesejahteraan dapat menurunkan tingkat kecemasan. Hasil pnelitian sama dengan penelitia terdahulu yang laporkan oleh Sugiyanto, (2014) bahwa pembekalan spiritual dapat menurunkan tingkat keecemasan sampai dengan $100 \%$.

Seseorang yang dapat pembekalan spiritual seperti diajari berdzikir dan berdoa yang dilakukan secera rutin dapat membuat pikiran menjadi lebih tenang (Aziz, 2011), berdoa juga dapat menurunkan stres dan dapat mengurangi gejala sauatu penyakit (Ferguson, Willemsen, \& Castañeto, 2009). Ketika seseorang mengalami suatu masalah maka dapat menimbulkan berbagai macam gejala dalam diri seseorang tersebut seperti perasaan tidak tenang, perasaan takut, namun perasan tersebut bisa berkurang bila mampu menangkan diri dan berdoa dan bertawakal (Medya Perdana, 1999). Berdoa dan tawakal dapat menimbulkan perasaan percaya diri, optimisme, ketenangan (Munif, 2017).

Hasil penelitian menunjukkan bahwa terdapat pengaruh antara pembekalan kesejahteraan spiritual terhadap tingkat kecemasan keluarga pasien ICU di RSD dr. Soebandi Jember dengan nilai koefisien korelasi Nilai Z -4261 dan asym sig sebesar 0.000 (nilai p). Hasil menunjukkan bahwa nilai $p$ $=0.000<, 0.05$. Hasil ini relevan dengan peneliti terdahulu bahwa terapi spiritual dapat menurunan kecemasan (Maimunah, 2011), Dzikir dapat menurunkan stres (Milatina, 2008), terapi spiritual mampu menurunkan cemas dan depresi (Ahamad Razak, Mustafa Kamal Moktar, 2013), terapi pendampingan layanan spiritual 
menurunkan kecemasan pasien pre operasiclose fraktur (Munif, 2017).

Kesejahteraan spiritual merupakan suatu proses menguraikan sifat ikatan yang dinamis dan harmonis antara diri, lingkungan dan Tuhan. Kesejahteraan spiritual yaitu proses pemahaman yang mendalam tentang pribadinya, sosialnya yang biasanya dapat ditandai dengan seseorag harmonis dengan diri sendiri, harmonis dengan orang lain, harmonis dengan lingkungan dan hubungan yang harmonis dengan Tuhan. (Ni Putu Sriyanti, Warjiman, 2015). Pembekalan spiritual atau juga bisa disebut terapi spiritual merupakan suatu bentuk terapi yang dapat menurunkan gangguan psikologis seperti cemas dan depresi, terapi ini dapat memberikan pengaruh pada penerimaan diri sehingga seseorang mampu menanggulangi gejala-gejala pikiran negatif seperti cemas dan depresi dan mampu memberikan kenyamanan serta mendorong individu lebih dekat dengan Tuhan dan menerima cobaan dari Tuhan (Ahamad Razak, Mustafa Kamal Moktar, 2013). Perawat merupakan tenaga kesehatan yang paling dekat dengan keluarga sehingga bila ia megalami ganguan kecemasan memilki pengaruh dan berpeluang untuk membantu menurunkan kecemasannya. Pembekalan spiritual sangat bermanfaat terutama bila keluarga pasien sedang mengalami kecemasan dan selam pereode sakit dan mempengaruhi keluarga dalam berpartisipasi dalam proses penyembuhan (Ni Putu Sriyanti, Warjiman, 2015).

Bimbingan spiritual pada keluarga dapat menimbulkan rasa optimisme dalam menghadapi persoalan hidup (Munif, 2017), bimbingan spiritual perlu dilakukan oleh petugas medis terutama perawat guna memenuhi kebutuhan psikososial/spiritual dan sagat penting untuk menciptakan rasa aman bagi keluarga ketika keluarga pasien menalami kecemasan (Medya Perdana, 1999). Sugiyanto, (2014) menyatakan bahwa dukunga spiritual dapat mengurangi kecemasan yang dialami oleh keluarga, dukungan spiritual dapat mendekatkan keluarga kepada Allah SWT sehingga memberi manfaat terhadap kesehatan termasuk mengurangi cemas, perasaan kesepian serta dapat meningkatkan kematang dalam ineraski social dan lebih baik bagi keluarga yang sedang mengalami kecemasan (Sugiyanto, 2014). Ristina Mirwanti, (2016) dalam penelitiannya menyatakan bahwa bimbingan spiritual dapat meningkatkan kesejahteraan spiritual yang tinggi dengan demikian keluarga yang sedang menghadapi musibah dapat memaknai hidupnya serta memiliki hubungan dengan Tuhan yang baik sehingga keluarga mampu menghadapi problem dan kecemasan menurun.

\section{SIMPULAN}

Berdasarkan hasil penelitian ini dapat disimpulkan bahwa:

1. Kecemasan keluarga pasien yang mengalami kecemasan paling banyak sebelum dilakukan pembekalan kesejahteraan spiritual adalah berat sekali 11 (36.7\%), berat10 $(33.3 \%)$ sedang 4 $(13.3 \%)$, ringan $3(10 \%)$ dan normal 2 (6.7\%).keluarga pasien. 
2. Sesudah

dilakukan

pembekalan kesejahteraan spiritual dari 30 keluarga pasien mengalami perubahaan tingkat kecemasan berat sekali 2 (6.7\%), berat 9 (30\%), sedang $8(26.7 \%)$, ringan 7 (23.3\%) dan normal 4 (13.3\%) keluarga pasien.

3. Ada pengaruh pembekalan kesejahteraan spiritual terhadap tingkat kecemasan keluarga pasien ICU di RSD dr. Soebandi Jember dengan nilai Z-4261 dan asim sig $0.000<, 0.05$

\section{SARAN}

1. Bagi pendidikan keperawatan Intervensi ini bisa digunakan untuk kasus yang lain selain pasien. Hasil penelitian ini dapat menambah pengetahuan baru dalam bidang dasar keperawatan,diharapkan institusi pendidikan memberikan materi tambahan tentang aspek spiritualitas dan pemberian asuhan spiritual sehingga lulusannya memiliki kompetensi yang memadai untuk melakukan asuhan spiritual.

2. Bagi Bidang Keperawatan

Hasil penelitian ini diharapkan dapat menjadi acuan dalam peningkatan kesejahteraan pasien melalui peningkatan kemampuan perawat dalam memberikan asuhan spiritual, dengan mengembangkan asuhan spiritual dalam suatu prosedur tetap (protap) kerja sehingga protap tersebut dapat dijadikan jaminan akan pelayanan secara komprehensif.
3. Bagi Rumah Sakit dr. Soebandi Jember

Hasil penelitian ini diharapkan dapat dijadikan acuan untuk elengkapi pelayanan islami yang sudah ada dan dijadikan produk unggulan di RSD dr.Soebandi Jember.

4. Bagi peneliti selanjutnya

Dapat dilanjutkan dengan responden yang lebih banyak sehingga hasilnya dan lebih bervariatif dan sehingga hasil bisa lebih maksimal.

\section{DAFTAR PUSTAKA}

Ahmad Razak, Mustafa Kamal Moktar, W. S. W. S. (2013).

Terapi spiritual islami suatu model penaggulangan gangguan depresi. Jurnal Dakwah Tabligh, 14(1), 141-151.

Aziz, R. (2011). Pengalaman spiritual an kebahagiaan pada guru agama sekolah dasar. Proyeksi, 6(2), 1- 11.

Freitas, Kimura, Ferreira. 2007. Family Members Needs at Intensive Care Unit: Comparative Analysis Between a Public and a Privat Hospital. Rev Latino-Am Enfermagem, 15 (1). 84-92

Ferguson, J. K., Willemsen, E. W., \& Castañeto, M. V. (2009). Centering Prayer as a Healing Response to Everyday Stress: A Psychological and Spiritual Process. Pastoral Psychology, 59(3), 305-329. doi:10.1007/s11089-009-02257

Hamid,A. 2008. Bunga Rampai Asuhan Keperawatan Kesehatan Jiwa. Jakarta: EGC 
$\begin{array}{rrr}\text { Hudak } & \text { Gallo. } & 2013 . \\ \text { Keperawatan } & \text { Kritis } & \text { Edisi } 6 .\end{array}$ Jakarta: EGC

Kementerian Kesehatan RI. 2010. Pedoman Penyelenggaraan Pelayanan Intensive Care Unit (ICU) di Rumah Sakit. Jakarta: Kementerian Kesehatan RI.

Kozier, B., et.al. 2004. Fundamental of Nursing: Concepts, Process, and Practice $\left(7^{\text {th }}\right.$ ed). New Elsevier

Maimunah, A. (2011). Pengaruh Pelatihan Relaksasi Dengan Dzikir Untuk Mengatasi Kecemasan Ibu Hamil Pertama.Jurnal Psikologi Islam, 8(1), 1-22.

Medya Perdana, Z. N. (1999). Bimbingan Terhadap Tingkat Kecemasan Pada Pasien Pre Operatif Di Ruang Rawat Inap RSUD Kajen Kabupaten Pekalongan.

Munif, A. (2017). Pengaruh pendampingan layanan spiritual doa dan tawakal terhadap tingkat kecemasan pasien pre op closed fracture di RS Muhammadiyah Lamongan. Universitas Airlangga Jakarta.

Rina Budi Kristianai, A. N. D. (2017). Komunikasi terapeutik dengan tingkat kecemasan keluarga pasien di ICU RS. Adi Husada Kapasari Surabaya. Adi Usada Nursing Journal, 3(2), 71-75.
Ristina Mirwantu, A. N. (2016).

Hubungan kesejahteraan spiritual dengan depresipada pasien dengan penyakit jantung koroner. Medisains, 14(April), 46-52. Sugimin. (2017). Kecemasan keluarga pasien di ruang ICU RSUP dr. Soeradji Tirtonegoro Klaten.

Universitas Muhhammdiyah Surakarta.

Sugiyanto, B. (2014).

Pengaruh konseling spiritual perawat terhadap tingkat kecemasan pada keluarga yang dirawat di Ruang ICU RSUD Sleman Yogyakarta. STIKes Aisyiyah Yogyakarta. 